\title{
TOWARDS NEW METHODOLOGIES IN MIGRATION AND DIASPORA STUDIES: AN INTRODUCTION
}

\author{
Leena Kurvet-Käosaar
}

Associate Professor of Cultural Theory

University of Tartu, Estonia

Senior Research Fellow

Estonian Cultural History Archives

Estonian Literary Museum, Estonia

leena.kurvet-kaosaar@ut.ee

\author{
Triinu Ojamaa \\ Senior Research Fellow \\ Estonian Cultural History Archives \\ Estonian Literary Museum, Estonia \\ triinu.ojamaa@kirmus.ee
}

\begin{abstract}
The introduction to the second part of the special issue, titled "On the Move: Migration and Diasporas", focuses on current methodological advances in the field, in particular on mixed-methods approaches and methods for studying digital diasporas as well as some related conceptual concerns, for example, the reemergence and critical revision of the concept of cosmopolitanism. The relevance of the contributions of the current issue to larger tendencies and theoretical debates on mobility and migration is outlined. Similar to the first part of the special issue (Folklore: Electronic Journal of Folklore, Vol. 78), the included articles address a variety of questions and problems concerning migration processes in Eastern European, Baltic, and Nordic contexts, methodologically engaging with virtual and multi-sited ethnography, autoethnography, multimodal analysis, and typologies of multilingual socialization, and utilizing a variety of sources, including archival materials, life writings, and literary production.
\end{abstract}

Keywords: borders, cosmopolitanism, (digital) diaspora, migration, networking, TSF

In the field of migration and diaspora studies, mobility does not only define processes, phenomena, and participants studied; it also applies to theories, concepts, and paradigms employed, which can be characterized by multifarious, 
entangled, and at times contradicting trajectories of evolvement and application. Some of these conceptual routes - embracing migration, diaspora, and transnationalism - were outlined in the introductory article of the first volume of the current special issue (Ojamaa \& Kurvet-Käosaar 2020). Closely related to conceptual and paradigmatic concerns, a look at the field from the vantage point of methods and sources makes visible further questions, additional developments, and complex inter-relations. There is a general agreement that research on international migration - which in multiple formats of mobility currently constitutes the field of migration and diaspora studies to a very extensive extent - requires varied competencies in, for example, cultural or linguistic terms, and poses multiple challenges when, for instance, having to tackle deficient or inaccessible sources of data or a complex set of ethical issues relating to the marginalized and underprivileged position of informant groups in the host society (Gold \& Nawyn 2013: 6; Bilsborrow 2016: 110). There is also an awareness of the relative scarcity of methods developed for doing research on international migration (Gold \& Nawyin 2013: 6) and diasporas (Smets 2019: 97 ), and a breach between the promise of theoretical frameworks and the availability of research tools that would enable us to offer conclusive and concrete scientific proof to theoretical assumptions (Boccagni 2012: 295). Though there is a sustained effort to envision migration and diaspora studies - which can also be viewed as two connected, yet separate fields - as one highly heterogeneous area of scientific inquiry, the selection of methods and utilization of sources and principles of gathering data in the field may be limited to more concrete disciplinary affiliations of researchers undertaking a particular project.

To an extent, this is evident from the way in which methods and methodological issues are presented in different handbooks within the field (see, e.g., Vargas-Silva 2012; White 2016). Even research on transnationalism, an area of scientific enquiry that has never been confined to one disciplinary framework, has methodologically tended to rely quite extensively on "single-method case studies" (Boccagni 2012: 312). At the same time, methodological concerns that play an important role within the central debates and discussions in the field clearly highlight the need for and development of new approaches and redesigning of the existing research methods. For instance, for the study of transnationalism, the analysis of census and other kinds of official data, longitudinal surveys and ethno-surveys, multi-sited and mobile ethnography and multi-sited matched samples have been suggested as viable methodological choices (Portes 2003: 889; Faist 2012: 51-70). 


\section{MIXED-METHODS APPROACHES}

The methodological initiatives attempting a coverage of the field (Vargas-Silva 2012; Gold \& Nawyn 2013; White 2016; also Volkmer 2012 and Ponzanesi 2019 for research on digital diasporas) highlight the importance of inter- and intradisciplinary discussions concerning methods, sources, and data, and make visible the extent to which such acts of positioning keep (re)defining the field. They also encourage researchers in the field to critically evaluate the suitability of mainstream methods within their given discipline for conducting research on international migration, and to develop new methods or utilize combinations of a variety of methods across a variety of disciplines and qualitative and quantitative approaches. Thus, for example, a section of the Handbook of Research Methods in Migration is dedicated to interdisciplinary approaches and mixed methods (Vargas-Silva 2012: 273-344) that "borrow from and build upon a diverse range of methodologies and methods" (Bose 2012: 273). In a similar vein, the section on methods of the Routledge International Handbook of Migration Studies introducing "the methods specifically designed for the collection and analysis of data on international migration" seeks to demonstrate the relevance of combining techniques of producing data and/or engaging with sources, analytical tools, and theoretical approaches from a variety of different fields (Gold \& Nawyin 2013: 479). Although methodological advances include a combination of a variety of different methods and utilization of new source types (see, e.g., Gold 2013 on photographs and other visual materials) and data sets (see, e.g., Woodrow-Lafield 2013 on reengineering and/or harmonizing censuses, and Risam 2019 for spatial data visualizations), there is a strong preference for mixed-methods or multiple-methods approaches, in particular for the study of transnational social space (see Lubbers \& Verdery \& Molina 2020 for an overview). Though these terms have been defined in a variety of ways, mixed methods most commonly refer to "research in which the investigator collects and analyzes data, integrates the findings, and draws inferences using both qualitative and quantitative approaches or methods in a single study or a program of inquiry" (Tashakkori \& Cresswell 2007: 4). Where distinguished from the former approach, the term 'multiple methods' is used to refer to sequential ordering of quantitative and qualitative components of research (Gamlen 2012: 320). More recently, the term 'convergent design' has been used for referring to research frameworks that bring together quantitative and qualitative types of data with an emphasis on examining different aspects of the studied phenomena, enabling us to gain insights into "multiple perspectives and subjective realities" (Fauser 2018: 402). 
The study of international migration in terms of transnationalism has been, to an extensive extent, based on the conceptual framework of the transnational social field (TSF), defined as "an unbounded terrain of interlocking egocentric networks that extends across the borders of two or more nation-states and that incorporates its participants in the day-to-day activities of social reproduction in these various locations" (Fouron \& Glick Schiller 2001: 544). Offering a socially rather than geographically defined concept of space, the TSF focuses on the ways in which "transnational processes unfold in social networks rather than ones circumscribed within national boundaries" (Lubbers \& Verdery \& Molina 2020: 179). Methodologically, the study of the TSF relies on social network analysis that is based on qualitative and mixed-methods approaches and "systematically collects, analyzes, and visualizes data about migrants' interpersonal relationships and aggregates them into social networks" (ibid.). This kind of research has taken prevalence in TSF research over qualitative approaches based on interviews, and multi-sited and mobile ethnography (see, e.g., Glick Schiller \& Fouron 1999; Fog Olwig 2007) due to limitations in qualitative methods in tackling the size and structure of transnational networks (Lubbers \& Verdery \& Molina 2020: 179). In research on the TSF, four main categories of social network analysis according to primary analytical focus can be distinguished - individuals, households, dyads / small sets, and communities (Lubbers \& Verdery \& Molina 2020: 183). Though research on transnationalism proceeding via social network analysis is dominantly quantitative, qualitative components, such as, for example, ethnographic fieldwork at a preliminary stage or research or "interpret[ing] the meaning of relationships, captur[ing] their dynamic nature, or enquir[ing] about networking processes" constitutes an important aspect of social network analysis, indispensable for successful TSF research (Lubbers \& Verdery \& Molina 2020: 197).

\section{STUDYING DIGITAL DIASPORAS}

Both in methodological and conceptual terms, the study of migration and the new media and different methods of conducting online research, which have emerged during the last decades, remain one of the focal points of research on international migration today. Of central importance here is the diminishing importance of territorial aspects and borders in defining identity in national terms as well as the overall reconfiguration of spatiality and locality, and the shift to the perception of nations as networks (Ponzanesi 2020b: 5, reference to Bernal 2014). Migration and new media are often discussed in terms of digital diaspora (or diasporas), used to refer to a number of phenomena and characteristic 
traits of migration in the contemporary world, such as technological mediation, formats or platforms of co-existence and social organization, technological mediation, and communicational uses of ICT connectivity (Andersson 2019: 145; Ponzanesi 2020b: 2-3). Digital diasporas are dominantly discussed in terms of the ways in which new digital technologies "enhance and diversify the role, impact and sustainability of diasporic connections" (Ponzanesi 2020b: 2) and support the development of transnational identity.

Alongside considering identity in transnational (also multi-transnational) terms, the concept of cosmopolitanism, shedding its formerly elitist connotations, has resurfaced as a viable identity category in migration and diaspora studies largely in the context of digital diasporas (Christensen 2012: 892). Highlighting the "simultaneous rootedness and openness to shared human emotions, experiences and aspirations" (Glick-Schiller \& Darieva \& Gruner-Domic 2011: 399), cosmopolitanism is viewed as offering a promising conceptual ground for discussions concerning questions of mediation of attachment, positionality, and openness (Christensen 2012: 893). Essential in the adoption of the term is a focus on the ways in which cosmopolitanism is practiced in concrete, everyday life situations that cut across and furnish new kinds of ties and alliances between different territorialities and national and socio-political configurations. The new ranges of implications of the term, often invoked as "cosmopolitanism from below", crucially rely on "[r]efugees, peoples of the diaspora, and migrants and exiles [who] represent the spirit of the cosmopolitical community" (Pollock et al. 2000: 577, 582). Within the current discussions of cosmopolitanism, attention is paid to its aspirational dimension; according to Ponzanesi (2020a: 2), "something that we should strive for to bring about a more equal and just world system". While connectivity, a term used first and foremost to refer to modes and possibilities of digital communication, harbours a great potential in terms of refiguring the perception of identity, it can only be realized via taking interest in, recognizing, and emphasizing the points of view, ideas, and beliefs that are different from ours, and developing a readiness to encounter and engage with the unfamiliar (Ponzanesi 2020a: 4, with reference to Zuckerman 2013 and Appiah 2007 [2006]). Digital cosmopolitanism, a term not limited to but deeply embedded in contemporary mobilities and diasporic patterns, can be defined as "the power of the internet to engage with the other and shape new networks of solidarity, contributing to intercultural exchanges, global justice, and new types of subpolitical activities/counterpublics" (Ponzanesi 2020a: 4).

As the brief overview provided above sought to demonstrate, a focus on digital diaspora(s) has brought about a paradigmatic shift concerning the perception of modes of engagement with the world with a very strong aspirational ethos. These developments, however, do not overlook "the power of technology to create 
bias, othering, and classifications" manifest in neo-colonial forms of exploitation (Ponzanesi 2020a: 4), and cultural othering or "high-tech orientalism" (Chun 2006: 77) visible, for instance, in Eurocentric and racialized perception of the ICT use. While access to networked technologies can be instrumental for the wellbeing and survival of refugees (Latonero \& Kift 2018: 4), international digital security and surveillance systems, for example, Frontex and Eurosur, Eurodac and PRIMES databases can be viewed as contributing to the enhancement of asymmetrical power relations and deepening existing inequalities (Ponzanesi 2020a: 6; Madianou 2019: 206).

While research on digital diasporas has, to a large extent, focused on underprivileged and vulnerable user groups, research categories also include middle class and student mobility and highly skilled migration (Andersson 2019: 145-146). The main foci of research in the area concern transnational affiliations and identity-construction processes and (everyday life) practices as well as online organizations, networks, social support structures, and cultural reproduction (ibid.: 149-150). Burgeoning research concerning the organization and perception of transnational family life has led to the development of a number of new terms such as, for example, e-family (Benítez 2012) and "care-giving at a distance" (Levitt 2009), and given rise to new conceptual frames, applicable both to concrete sets of practices and modes of self-perception that prioritize virtual co-presence (Baldassar 2008; see also Hovgaard 2015 for dual presence; Madianou 2016 for ambient co-presence).

Digital diasporas can be viewed as the most active and most rapidly developing area of migration and diaspora studies today. Methodologically, research in the field can be categorized in terms of virtual ethnography, connective approaches, studies of the Internet in everyday practices, and digital humanities and big data research (Andersson 2019: 160). A slightly different paradigmatic-methodological typology, featuring mediacentric cyber culture studies, non-mediacentric ethnographic approach, and mediacentric digital approach (data-driven network analysis) has been proposed by Candidatu and Leurs and Ponzanesi (2019: 36, Table 3.1). The mediacentric approach that emerged in the 1990s proceeded from the assumption that "to understand what is happening in cyberspace, only what happened in it was of relevance" (ibid.: 37). The focus of virtual ethnography (also netnography) is similar, requiring, however, that the researcher retained an awareness of the complex interrelationship between online and offline activities and the ways in which the mediation of offline experience is altered and/or amplified by the Internet (Kozinets \& Dolbec \& Earley 2013: 264). Interest in exclusively online studies of the Internet has gradually been replaced by connective approaches that turned attention to the role of online communication in socialization processes as a whole. Neverthe- 
less, mediacentric research is considered valuable for increasing the visibility of marginalized, relatively understudied ethnic groups from the perspective of cultural production and self-representation (Candidatu \& Leurs \& Ponzanesi 2019: 38). For the study of migrant lives, the connective or non-mediacentric approach that undertakes joint investigation of real and virtual dimensions of diverse aspects of cultural and social phenomena and processes, has contributed greatly to the study of everyday life, including domestic, intimate, and familial contexts (Candidatu \& Leurs \& Ponzanesi 2019: 38-39; see also Baldassar 2008; Hjorth \& Lim 2012; Witteborn 2019) and questions of virtual and physical locality and translocality (Witteborn 2014; Christou \& Sofos 2019; Christensen 2012). For this approach, research in cyberspace (digital ethnography) is combined with conventional and multi-sited ethnography (Andersson 2019: 164). As was pointed out before, social network analysis (also issue mapping and hyperlink analysis, see Alinejad et al. 2019 for a novel application) as a quantitatively based approach incorporating elements of qualitative analysis has more recently emerged as the leading approach for the research on international migration within the context of the TSF (see Lubbers \& Verdery \& Molina 2020 for a comprehensive overview). These methodological developments aiming at comprehensiveness, which lean towards digital humanities and big-data approach, have shifted the theoretical focus to "human-machine entanglements", such as, for example, "object-oriented ontology, new materialism, posthumanism, actor-network theory" (Candidatu \& Leurs \& Ponzanesi 2019: 39). In the light of these developments, theorists of digital diaspora have voiced the need to reconceptualize digital diaspora by bringing together earlier feminist and postcolonialist conceptualizations of diaspora with the study of diasporic online practices in digital humanities frameworks (ibid.: 41-42).

\section{CONTINUING THE DISCUSSIONS ON MOBILITY: INTRODUCTION TO THE ARTICLES}

Although questions concerning digital diasporas have been among the most topical and most actively studied areas in the field of migration and diaspora studies, research in the field still proceeds along a great variety of different foci and points of interest that concern different periods in the migration history, diverse socio-cultural contexts, and aspects of the diaspora as such. Researchers utilize a wide variety of data collected in different ways and materials obtained from different sources, applying a range of different methods, some of which are more novel while others have been in use for more than a century. In the second part of the special issue of Folklore: Electronic Journal of Folklore, 
titled "On the Move: Migration and Diasporas", both virtual and face-to-face communication and networking of contemporary immigrant groups have been analysed, utilizing virtual and multi-sited ethnography. In addition, the formation processes of diaspora communities that began to develop as a result of the sixteenth-century migration waves are also under discussion, based on extensive ethnographic fieldwork. Several articles engage with various archival sources and life writings of concrete diasporic individuals of prominence in cultural and political life to discuss questions of identity and socio-cultural impact on diaspora communities. The expression and reflection of mobility in relation to borders in various forms of visual and verbal arts and folklore have also been examined from the autoethnographic perspective, also applying multimodal analysis and typologies of multilingual socialization.

The article by Eva Toulouze and Nikolai Anisimov, "An Ethno-cultural Portrait of a Diaspora in Central Russia: The Formation and Culture of the Eastern Udmurt", is based on the authors' ethnographic fieldwork material collected in 2013-2019, and is framed by a historical overview on Russia's economic ambitions and military actions which were followed by several migration waves. The study focuses on the formation and development of a small diaspora community that has left their original Udmurt territory and is now known as the Eastern Udmurt. The part of the former Soviet Union where their area of settlement is located became accessible to Western researchers step-by-step only in the 1990s (Lintrop 1993: 5). We can find very little data on the Udmurt in English; Rein Taagepera's monograph titled The Finno-Ugric Republics and the Russian State (1999) seeks to fill this cap. The fact that the area has been closed to foreign researchers seems to give it a certain exotic connotation; partly, one may perceive even some poetic undertone in Taagepera's presentation of the Udmurt community. He describes Udmurtia as an area between the Volga River and the Ural Mountains, "where one meets many redheaded people. ... Udmurts say, 'A person with red hair is the sun's child', and 'a redheaded person is closest to the gods"' (Taagepera 1999: 253). The author also mentions that the Udmurt identify themselves as "Europe's last animists" (ibid.). Taagepera is probably the first researcher who, speaking about the Udmurt ethnic group, brings into use the term 'diaspora'. Unlike Toulouze and Anisimov, he does not explain the use of the term - the diaspora as such is not his subject. Toulouze and Anisimov use the term 'diaspora' only with regard to the Western Udmurt, i.e. the group which separated from the rest of the Udmurt ethnos and formed a diaspora. The authors briefly explain that they base the term on the common idea according to which "a diaspora is an ethnic group separated from its historical core territory but feeling a connection 
with it" (Toulouze \& Anisimov 2020: 32). They manifest that their aim "is not to develop a discussion on the theoretic notion of diaspora" (ibid.); nevertheless, their article directs the reader's thoughts to the much-debated question: whose belonging to this social category is justified? Discussions on this subject have lasted at least since William Safran's "Diasporas in Modern Society: Myth of Homeland and Return" was published in 1991. Today it has acquired a status of a classic, but the debate carries on. Safran's work has been followed by a number of theoretical developments which seek to penetrate, in more detail, the nature of this phenomenon not fully grasped yet, and at the same time the semantic field of meaning of the term 'diaspora' continues to expand. In Russia, amongst the administrative units today's Udmurt Republic belongs to, the concept of diaspora has been gradually added to the academic vocabulary over the last decade and it appears to have both proponents and opponents among the researchers with roots in the Soviet scientific tradition. In the context of this tradition, the Udmurt have always belonged to 'small nations' or national minorities of a multicultural (Soviet) Russia; for example, in the article "Are National Minorities of the Former USSR Becoming New Diasporas? The Case of the Tatars of Kazakhstan", Yves-Marie Davenel (2009) discusses the situation behind the spread of the concept of diaspora in Russian social sciences. With regard to the Eastern Udmurt case, we would like to draw readers' attention to an approach that offers a relatively original solution to the problem of being or not being a diaspora community. Takeyuki (Gaku) Tsuda opines that diaspora is not an absolute state; he proposes a notion of diasporicity that "refers to the relative embeddedness of dispersed ethnic groups in transnational connections to both their ancestral homeland and to their co-ethnics scattered in various countries around the world" (Tsuda 2019: 189). Instead of discussing "whether a dispersed ethnic group is sufficiently diasporic to qualify as a diaspora", Tsuda considers it appropriate to address the question "How diasporic are they and why?" (ibid.: 195). When choosing this path, the preservation of ethnic religion could be an important yardstick for deciding on diasporicity. Although the preservation of religion is considered one of the core issues of diasporic identity, it has received relatively little attention in the context of research on diaspora, especially as compared to, for example, ethnicity (Baumann 1998: 96, 2018: 36-37). According to Robin Cohen (1997: 189), religion can function as an "additional cement to bind a diasporic consciousness". Usually, debates about the relationship between diaspora and religion revolve around world religions (see, e.g., Vertovec 2018), but here we would like to highlight the study by Toulouze and Anisimov especially because, among other essential cultural characteristics, the authors also analyse the relationship between diasporic identity and 
ethnic or vernacular religion (defined as 'paganism' in the Eastern Udmurt community), thus demonstrating how any kind of religion can function as an important axis of one's group identity.

The roots of the article by Irina Belobrovtseva, "Seto People in the Expedition Diaries and Literary Works of a Russian Émigré Leonid Zurov", reach back to the author's earlier work with Zurov's manuscript collection in the Russian Archive of Leeds University, which contains correspondences, diaries, and fieldwork notes thoroughly described in her contribution to the collection of articles Inimese Muuseumi ekspeditsioonid Eestisse. Boris Vilde ja Leonid Zurov Setomaal (1937-1938) (Expeditions of the Museum of Man to Estonia. Boris Vilde and Leonid Zurov in Setomaa (1937-1938)) (see Belobrovtseva 2017: 125-133). In this special issue, Belobrovtseva discusses some of the lesser-known aspects of Russian migration history through an analysis of Zurov's activities. As a result of the wave of migration caused by the October Revolution, several émigré centres developed in European metropolises but from the point of view of Belobrovtseva's study the new small border states of the former Tsarist Russia, such as Estonia, Latvia or Finland, which due to their geographical proximity became the first destination countries for many émigrés, are more important. Over time, these countries began to play a specific role in the lives of Russian émigrés (Belobrovtseva \& Meimre 2015: 31-34). Belobrovtseva analyses various aspects of Zurov's mission - restauration works in the Pskovo-Pechersky monastery, archaeological and ethnographic fieldworks that he conducted in the Russian-Estonian border areas, demonstrating how those journeys helped Zurov to enter into a dialogue with the past of his nation. In a sense, this dialogue was filtered through the culture of 'others', i.e. Seto people who inhabit this borderland and whose vernacular religion is "a kind of 'double faith" (Oinas 1974: 18), in which the Christian tradition, defined by Oinas as "Greek-CatholicByzantine elements mediated by the Russian Orthodox", exists in "a curious symbiosis with heathen traits" (ibid.). Belobrovtseva argues that Zurov believed that Setos preserved the ancient Slavic rites better than Russians.

In the context of the diaspora discourse, Zurov's case can be associated with the topic "myth of homeland and return" (Safran 1991), the main idea of which is that the diasporans' desire to go back is always there, even if it is unrealistic. As demonstrated by several case studies, the diasporans' return journey usually remains a wishful dream but it can also become a reality like, for example, in the case of Germans' 'return tourism' to their pre-World War II homes after the fall of the Iron Curtain (Bierwerth 2015), or in the case of Palestinian Swedes who build another home in their country of origin to teach their children the traditional Palestinian culture (Gren 2015). Russian émigrés discovered their own way: in the 1920s-1930s, holiday trips to the Estonian-Russian border areas 
became popular among them. Their holiday trips have features similar to the post-World War II return tourism, and although Russian émigrés could not cross the border and step on their land of origin, the proximity of the homeland was perceived in the most direct sense: this land could be seen across the border as Belobrovtseva (2020: 61) describes. Zurov's journeys to the Russian-Estonian border area reflect the dual nature of the border as such, i.e. in certain cases, in addition to separation, it can have some unifying effect.

Belobrovtseva's analysis highlights Zurov's role as an integrator of Russian diasporans; his activity might strengthen the compatriots' sense of belonging to both diaspora community and homeland. But in this connection, we would also like to address one case that shows how a sense of belonging to one's homeland can be shaded by a sense of injustice from being robbed of a homeland. As it is known, Leonid Zurov as a young émigré writer was the protégé of the famous Nobel Prize winner Ivan Bunin. In 1938, Bunin visited Estonia and the other Baltic countries; the tour was organized by his impresario with the aim of presenting his literary works. In an interview with the newspaper Uus Eesti (New Estonia) (1938: 4), Bunin states that he does not feel any longing for his real homeland because he does not like its regime and in addition to that his home in France is as beautiful (as Russia). But in her article, Belobrovtseva writes that in a photograph taken by Zurov during his expedition to the border, Bunin saw an old stone cross, and as a result, he "expressed a wish to have such a cross put on his grave" (Belobrovtseva 2020: 62). Behind Bunin's wish one can detect a need for a somewhat eternal link with his real homeland. As regards Zurov, when analysing his activity in the 1930s and its wider aftereffect, Belobrovtseva presents him as a diasporic personality with an extraordinary capacity to encourage his compatriots' sense of belonging to homeland. However, Belobrovtseva emphasizes that Zurov felt deep respect not only for Russian history and culture but also for the history and culture of 'others'; thus, he was not just an embittered nation-centric émigré.

In several case studies it becomes apparent that in the eyes of diasporans the borderlands of their country of origin may be alluring and attractive. On an emotional level, people who have been forced to leave home at different times appreciate the possibility of being close to the border quite similarly. For example, when their economic conditions had improved, it became customary among Estonian World War II overseas refugees to travel to Europe to spend their holidays there. Finland was the country that enabled them to get as close as possible to homeland. Belobrovtseva's (2020: 61) article contains an excerpt from Zurov's letter to Vera Bunina from 6 June 1935 about how he, when visiting the Estonian-Russian border area, could see with his own eyes a Russian village on the other side of the border, which was just a conventional line. 
Between Finland and Estonia there were eighty kilometres of the Baltic Sea, yet in spite of that, visiting the coast became a tradition among Estonians. For example, in 1964, the Toronto Estonian Male Choir, which consisted of former war refugees, made a concert tour in Europe and their concerts also took place in Finland. The host ordered a bus that took the singers to a cape near Helsinki, where the coast was flat, so that the men could look in the direction of Estonia unhindered. For the programme booklet of Finnish concerts, Estonian-Canadian poet and writer Arved Viirlaid wrote verses in which he compares going to the border of Estonia, which was occupied by the Soviet regime, with standing in front of a prison gate. In order to make a closer or more real connection with the homeland that the eye cannot reach, a refugee must throw a stone into the water to give rise to a wave that lands on their home coast (Ojamaa 2011: 140).

Visits to Finland also played an important role in the life of Ivar Ivask, a writer and literary scholar of Estonian and Latvian background. While living in Northfield, USA, Finland became a "Baltic surrogate, a substitute for the homeland" for him (Olesk 2007: 6), but he also had a deep interest in Finnish and Finno-Ugric cultures. Here one can see clear parallels with how the Baltic countries had been a substitute for the homeland for Russian émigrés in the first decades of the twentieth century. Aija Sakova and Marin Laak analyse Ivar Ivask's creative choices and their influencing factors in the article "Situating Oneself within the Estonian Language and World Literature: Ivar Ivask's Relational Ways of Self-understanding". Similar to the other writers who in the course of World War II fled from the eastern part of Europe to the west, literary scholars treat Ivask as an exile writer; in the post-war decades, the term 'diaspora' and the notion 'diasporic writing' were not common in literary studies. The work of exile writers consisted of "approximately equal proportions of literature of political struggle and literature of elegiac or indignant reminiscence" (Oras 1967: 10) and in line with the expectations of the exile society, they felt a moral responsibility for the preservation of the language and culture of origin, keeping their fellow refugees in the sphere of influence of the culture that was based on native language (Estonian National Council 1956: 11; on the goals of Latvian exiles see, e.g., Bela 2011). Although exile writers usually used two languages in their everyday communication - the language of origin and that of the host country - most of their work was monolingual, less often bilingual. According to Zuzanna Olszewska (2019: 87), the diasporic writers usually position themselves either in relation to the homeland, struggling for keeping alive their native culture, or the host country; in both cases their choice of language depends on orientation. The study by Sakova and Laak shows that Ivask is an exception on the landscape of exile literature, and his understanding of himself as well as his positioning himself as a writer cannot 
be treated just in terms of binarity (i.e. belonging to the culture of the country of origin or that of the host country). The authors analyse Ivsak's background and demonstrate how diverse and complicated it was: Ivask as a multilingual writer felt himself at home in far more than only two cultures. Ivask's phenomenon has been of interest to literary scholars and critics since his appearance in the arena in the 1950s, but Sakova and Laak approach him as a creative person from a new angle, using Ivask's personal collection preserved at the Estonian Cultural History Archives in the Estonian Literary Museum in Tartu (diaries and correspondences in various languages). Applying the concept of relationality, Sakova and Laak explore Ivask's work through his "relational or proximate others" (2020: 71-90), which include his family members but also the global network of writers appreciated by him. Analysing Ivask's connections with the natural and cultural environments of his childhood, as well as his later life that took him to different parts of the world, the authors strive to illuminate the reasons for Ivask's language shift from German to Estonian in his poetry and diaries. In Sakova and Laak's view, Ivask was a cosmopolitan or world citizen, and, relying on Ivask's essays (e.g. Ivask 1951), it can be said that this view coincides largely with his own self-image. The concept of cultural nomadism had not yet gained as much popularity in the times of Ivask's literary activity as it has today, but with reservations, his way of being a writer could also be brought under this notion, based, for example, on how Elina Mikkilä, speaking about non-monolingual writers, has interpreted cultural nomadism in this special issue.

In the article "Literary Biographies without a Fixed Linguistic Abode", Elina Mikkilä takes under observation migration writers' language choices and migration literature in its historical development. Mikkilä defines the migration literature as "a genre on the move" (2020: 106). For Mikkilä, the mobility of literature is primarily associated with the writers' nomadic lifestyle. In the humanities, the concepts of nomadic lifestyle and new nomadism have been circulating already since the 1990s. Their connection with the traditional nomadic way of life lies only in the fact that it refers to people with no settled home but moving from place to place. The so-called new nomads do not move by families, looking for food somewhere in the steppe or tundra; they prefer metropolises. Similar to a sparsely populated natural environment, the overcrowded metropolis enables them to experience solitude or the feeling of 'being alone together', and this is the reason why these are suitable surroundings for the modern creative intelligentsia who identify themselves as new or cultural nomads; Eva Hoffmann (1999) has compared their lifestyle with exile, referring to several common traits. When speaking about cultural nomads, their permanent being on the move has usually been emphasized, although in 
reality not all of them practise world travelling. According to Rosi Braidotti (1994: 5), cultural nomads' trips "can take place without physically moving from one's habitat. It is the subversion of set conventions that defines the nomadic state, not the literal act of traveling". In the context of migration, the cultural nomads physically on the move can be classified as voluntary migrants: they live their cosmopolitan lives based on individual choice, easily adapting to any new cultural and linguistic environment. However, as Tuija Saresma (2019) shows in the study about Mohsen Emadi, a multi-lingual poet and translator with Iraqi background, in some cases nomadism can include a certain forced component as well.

Migration writers realize their mobile lifestyles in different ways and this is also reflected in their literary works and language choice. In her article, Mikkilä presents an attempt to create some order and explain more systematically the peculiarities of migration writers and literature. This genre seems to be on the move not only because the writers are on the move, but also because it is still looking for its outlines. The characteristics of the genre are unclear; it does not even have a definite conventional name: Mikkilä lists more than ten terms that are used in the German-speaking world. The central concept of Mikkilä's article is 'language biography', which denotes the mode of bi- and multilingual "socialization of migration authors" (Mikkilä 2020: 95). Relying on the authors' language biographies, poetological material, and personal writing experiences, Mikkilä proposes a typology of non-monolingual literary writing. The languagebiographical typology demonstrates writers' various possibilities of becoming or being non-monolingual. It consists of five groups, including the naturally and culturally bilingual authors, diglossic authors, and foreign-language authors. In compiling the typology, Mikkilä is primarily interested in contemporary migration writers, but in general the types she describes can also be found in literature belonging to earlier times, including the post-World War II exile literature which still has not lost its historical value. Mikkilä's article focuses on the literature created by culturally bilingual authors who have developed their skills of literary writing in some other language as their own, and she as a researcher-author is one of them. The fact that Mikkilä analyses the background of her personal literary self and the positive and negative experiences related to creative practices gives the study a strong autoethnographic added value. It is noteworthy that sooner or later multilingual authors reach the need to discuss their writer identity, probably feeling some inner need to position themselves in the particular literary landscape in which they operate. In this special issue, we can also find some references to such a need in the article by Sakova and Laak, and here we again recall Saresma's (2019) study about Mohsen Emad, which perfectly demonstrates coherence between one's literary writing, language choice, and mobile lifestyle. 
We draw attention to the experimental orientation in Mikkilä's research, which is to some extent related to typology and is also based on her wider interest in writing and thinking in several languages. The author presents an experiment, in the course of which her auto-fictional prose narrative "Mütter Land" was translated into different languages, using the machine translation service. The experiment showed how unpredictable the links between languages and cultures, which become apparent via a digital translation process, can be.

The article by Kari Korolainen, "Graphic Aspects of Mobility: FolkloristicEthnological Drawings as a Starting Point for Discussing Mobility and Borders", introduces the reader to the folkloristic material collected from the eastern part of Finland and Finnish and Russian Karelia in 1936-1939, which is now preserved in the folklore archives of the Finnish Literature Society. Korolainen examines the handwritten texts of ordinary people, which describe an object, activity or situation; the documents also include hand-made drawings. By applying multimodal analysis, the author reveals the relationship between the text and drawings. The article contains multi-layered discussions on mobility, first and foremost, in the context of folklore, but the author also exemplifies mobility with his own original drawings. In addition to his research activity, Korolainen is also known as a visual artist. He recently published a comic album Marjatta \& Ilman Kinna (Korolainen 2020a) ${ }^{1}$, which also points to the author's interest both in folklore and mobility issues - one of the key characters is traveller Kinna Ilma.

What is the symbiosis of a combination of a researcher and a creative personality, be it a visual artist, writer or representative of some other field? This is a wide topic to which Korolainen contributes with the current article, but he has dealt with the researcher-artist interaction issue also in some previous studies. According to Korolainen (2019), the researcher's being an artist can support research work in various ways. In his conference presentation titled "Drawing folklore, things and borders: Making of comic art and the study of folkloristic archive materials" Korolainen argues that "art-making can help recognising presumptions in research" and it also "offers 'tracks' for approaching (immaterial) folklore". But what is particularly important, art-making also "stimulates discussions about concepts, theoretical and ethical issues" (ibid.). In the article published in the special issue, Korolainen moves deeper into this topic. He also looks in the opposite direction, i.e., he seeks the efficiency of research work for art making. Based on individual experience, he concludes that analysing folkloristic drawings serves as an inspiration source for him as a visual artist. Korolainen's article gives an idea of how diffuse the boundaries between one's creative and academic practices and thus also between creative and academic self can be. A person can belong to different groups simultaneously, thereby 
obtaining a kind of 'two-in-one' professional quality: an artist-researcher or a writer-researcher, if we speak about the authors in the current special issue.

Korolainen investigates mobility in relation to borders. All folkloristic examples indicate - directly or indirectly - the existence of boundaries, whether visible and clearly marked or invisible but perceived in some other way. Delving into his untitled cartoons (Fig. 7 and 8) one can presume that the question about perceiving the borders and possibilities to visualize them also addresses him as an art maker. Korolainen (2020b: 128) concludes his article with a rhetorical question, "[I]f the border is somehow imperceptible, does it necessarily indicate that it is un-representable?" The clear answer faces the reader from his own cartoons.

At present mobility, borders, and boundaries, and their visual representation are becoming more and more topical in relation to the corona pandemic. The rapidly changing conditions for mobility are a very new reality; therefore we can find only the first academic contemplations of social scientists and humanitarians on the links between mobility and pandemic. For example, Robin Cohen (2020) writes about 'panic movers' who leave cities to survive pandemic times in their safer country homes. The first studies have also been published in the field of folkloristics and the representation of virus-related things by visual means comes to the fore (see, e.g., Kuperjanov 2020). When taking a look at the Internet, one can see that it is full of different types of drawings, most of which visualize the new social norms. Corona does not respect borders - this is the common belief emphasized by doctors, columnists, and politicians. However, the whole world seems to be fighting the pandemic by setting all kinds of new boundaries. A great majority of the visual representations are related to keeping distance and very often they represent border areas between people, fulfilled with two meters of conventional emptiness. But one can also find drawings of demarcative constructions; for example, a transparent wall between two people with laptops, communicating from a distance.

Tanya Matanova's contribution to the special issue, "German Migrants in Bulgaria and Their Social Networks", presents the results of a pilot study, the focus of which is on immigrants' various communication practices. Diasporic communities have always relied on networks; Michel Bruneau (2010: 48) characterizes diaspora as a "patchwork of various networks" that functions "as a hinge between different spaces and different geographical scales. Their [diasporans'] networks belong to each of the host countries as well as to a transstate diasporic network" (ibid.). Nowadays, the Internet as "a meeting point" plays an irreplaceable role in the formation of communication; it has become the central framework for networking (Kissau \& Hunger 2010: 246-247). Speaking about the Internet in the context of migration and diaspora, Andoni Alonso and 
Pedro J. Oiarzabal (2010: 1-2) characterize it as a window into the immigrant's destination country, which at the same time functions also as an "interactive link back to their homelands".

Matanova's pilot is an internet-based research complemented by ethnographic interviews. She uses the data obtained by following the communication activities in sixteen German-language Facebook groups, the members of which share different kind of information about life in Bulgaria. The pilot is innovative primarily because of the attempt to visualize relationships between the members of the Facebook groups utilizing the programme VennMaker. Matanova points out an interesting fact: the network is not limited to the members of the German diaspora group, which has been developing in Bulgaria for some time; the members' profiles show that networking also includes so-called potential immigrants who, even if they never immigrate to Bulgaria, want to learn something about the country, its culture, customs, etc. Analysing relationships in the German immigrant group, Matanova classifies the members of the group into labour, student, family, and retirement migrants. We highlight the fact that Matanova includes in her research retirees, who do not very often find their way to the collective picture of migrants. Previous studies have addressed this category rarely, albeit from quite different perspectives. For example, Anoeshka Gehring focuses on the "lived EU citizenship", concluding that a certain part of Northern European retirement migrants, who had moved southward, including Bulgaria, really identify with Europe as a post-national entity, but the study also indicates that a warmer climate plays an important role in migrants' decision-making (Gehring 2019: 265-266). Marion Repetti, Christopher Phillipson, and Toni Calasanti (2018) observe, first of all, the economic aspect; their study demonstrates that Northern European retirees leave their homeland, hoping to improve their financial situation in the Mediterranean countries. As for German retirees, Stoyan Nenov and Thomas Escritt (2020) argue that their outmigration shows a growth trend. In 2002, 107 Germans were getting their state pensions wired to Bulgaria and by 2018 it was 652 , but in Thailand the increase was even from 671 to 5,415 . If we look at the retirees' outmigration from the networking perspective, we can find some indications in the media that this may lead to a loss of ties with family members in their homeland, as it has happened to several retirees in Thailand (ibid.). In our opinion, the retirement migrants' networking abilities on the one hand and the emotional aspect of meeting or dissatisfying their needs for communication on the other hand are worth a further research. Matanova's study as well as some others (e.g. Pileva 2020) show that elderly diasporans may not have their personal social media accounts and therefore their access to the new ICTs may depend on the support of the younger generation. Matanova's research also reveals 
the fact that online networking is, to a large extent, only a path along which diasporans can move to face-to-face contacts; people's need for this type of communication has not disappeared.

\section{ACKNOWLEDGEMENTS}

The article was supported by the research grant of the Estonian Literary Museum EKM 8-2/20/1 and by the Centre of Excellence in Estonian Studies (TK 145) through the European Regional Development Fund.

\section{NOTES}

1 See also https://kirjokansi.omaverkkokauppa.fi/Kari-Korolainen-Marjatta-IlmanKinna, last accessed on 16 July 2020.

\section{REFERENCES}

Alinejad, Donya \& Candidatu, Laura \& Mevsimler, Melis \& Minchilli, Claudia \& Ponzanesi, Sandra \& Van der Vlist, Fernando N. 2019. Diaspora and Mapping Methodologies: Tracing Transnational Digital Connections with 'Mattering Maps'. Global Networks, Vol. 19, No. 1, pp. 21-43. https://doi.org/10.1111/glob.12197.

Alonso, Andoni \& Oiarzabal, Pedro J. 2010. The Immigrant Worlds' Digital Harbors: An Introduction. In: Andoni Alonso \& Pedro J. Oiarzabal (eds.) Diasporas in the New Media Age: Identity, Politics, and Community. Reno, Nevada: University of Nevada Press, pp. 1-15.

Andersson, Kerstin, B. 2019. Digital Diasporas: An Overview of the Research Areas of Migration and New Media through a Narrative Literature Review. Human Technology, Vol. 15, No. 2, pp. 142-180. http://dx.doi.org/10.17011/ht/ urn.201906123154.

Appiah, Kwame A. 2007 [2006]. Cosmopolitanism: Ethics in a World of Strangers. New York \& London: W. W. Norton.

Baldassar, Loretta 2008. Missing Kin and Longing to Be Together: Emotions and the Construction of Co-presence in Transnational Relationships. Journal of Intercultural Studies, Vol. 29, No. 3, pp. 247-266. https://doi.org/10.1080/07256860802169196.

Baumann, Martin 1998. Sustaining "Little Indias": Hindu Diasporas in Europe. In: Gerrie ter Haar (ed.) Strangers and Sojourners: Religious Communities in the Diaspora. Leuven: Peeters, pp. 95-132.

Baumann, Martin 2018. Conceptualizing Diaspora: The Preservation of Religious Identity in Foreign Parts, Exemplified by Hindu Communities outside India. In: Klaus Stierstorfer \& Janet Wilson (eds.) The Routledge Diaspora Studies Reader. London \& New York: Routledge Taylor \& Francis Group, pp. 36-40. 
Bela, Baiba 2011. Exile as a Catalyst for Values. In: Ieva Garda Rozenberga \& Mara Zirnite (eds.) Oral History: Migration and Local Identities. Riga: University of Latvia \& Latvian Oral History Research Association Dzivesstasts (Life Story), pp. 8-22. Available at https://www.szf.lu.lv/fileadmin/user_upload/szf_faili/ Petnieciba/sppi/mediji/Oral_History_2011.pdf, last accessed on 16 July 2020.

Belobrovtseva, Irina 2017. Ülevaade 1928., 1935., 1937. ja 1938. aasta arheoloogiliste ja etnograafiliste ekspeditsipoonide materjalidest Leedsi Ülikooli Vene arhiivis. [Materials of Leonid Zurov's Archaeological and Ethnographic Expeditions of 1928, 1935, 1937 and 1938 in the Leeds University Russian Archive.] In: Tatiana Benfoughal \& Olga Fishman \& Heiki Valk (comps.) Inimese Muuseumi ekspeditsioonid Eestisse. Boris Vilde ja Leonid Zurov Setomaal (1937-1938). Seto Instituudi Toimetised, 2. Tartu: Tartu Ülikooli ajaloo ja arheoloogia instituut \& Seto Instituut, pp. 125-133.

Belobrovtseva, Irina 2020. Seto People in the Expedition Diaries and Literary Works of Russian Émigré Leonid Zurov. Folklore: Electronic Journal of Folklore, Vol. 79, pp. 59-70. https://doi.org/10.7592/FEJF2020.79.belobrovtseva.

Belobrovtseva, Irina \& Meimre, Aurika 2015. Sõdadevaheline vene emigratsioon suures ilmas ja väikeses Eestis. [Interwar Russian Emigration in the Larger World and "Little Estonia".] Methis: Studia humaniora Estonica, Vol. 12, No. 15, pp. 28-46. https://doi.org/10.7592/methis.v12i15.12114.

Benítez, José Luis 2012. Salvadoran Transnational Families: ICT and Communication Practices in the Network Society. Journal of Ethnic and Migration Studies, Vol. 38, No. 9, pp. 1439-1449. https://doi.org/10.1080/1369183X.2012.698214.

Bernal, Victoria 2014. Nation as Network: Diaspora, Cyberspace, and Citizenship. Chicago \& London: The University of Chicago Press.

Bierwerth, Gesa 2015. The Process of Integration among German Expellees in the GDR. In: Florian Kläger \& Klaus Stierstorfer (eds.) Diasporic Constructions of Home and Belonging. Berlin: De Gruyter, pp. 163-182.

Bilsborrow, Richard E. 2016. Concepts, Definitions and Data Collection Approaches. In: Michael J. White (ed.) International Handbook of Migration and Population Distribution. Heidelberg \& New York \& London: Springer, pp. 109-156.

Boccagni, Paolo 2012. Even a Transnational Social Field Must Have Its Boundaries: Methodological Options, Potentials and Dilemmas for Researching Transnationalism. In: Carlos Vargas-Silva (ed.) Handbook of Methods in Migration. Cheltenham, UK \& Northampton, MA: Edward Elgar Publishing, pp. 295-318.

Bose, Pablo S. 2012. Mapping Movements: Interdisciplinary Approaches to Migration Research. In: Carlos Vargas-Silva (ed.) Handbook of Methods in Migration. Cheltenham, UK \& Northampton, MA: Edward Elgar Publishing, pp. 273-294.

Braidotti, Rosi 1994. Nomadic Subjects: Embodiment and Sexual Difference in Contemporary Feminist Theory. New York: Columbia University Press.

Bruneau, Michel 2010. Diasporas, Transnational Spaces and Communities. In: Rainer Bauböck \& Thomas Faist (eds.) Diaspora and Transnationalism: Concepts, Theories and Methods. Amsterdam: Amsterdam University Press, pp. 35-49. 
Candidatu, Laura \& Leurs, Koen \& Ponzanesi, Sandra 2019. Digital Diasporas: Beyond the Buzzword. Toward a Relational Understanding of Mobility and Connectivity. In: Jessica Retis \& Roza Tsagarousianou (eds.) The Handbook of Diasporas, Media, and Culture. Chichester: Wiley-Blackwell, pp. 31-47.

Christensen, Miyase 2012. Online Mediations in Transnational Spaces: Cosmopolitan (Re)formations of Belonging and Identity in the Turkish Diaspora. Ethnic and Racial Studies, Vol. 35, No. 5, pp. 888-905. http://dx.doi.org/10.1080/01419870 .2011.628039.

Christou, Fanny \& Sofos, Spyros 2019. Physical and Virtual Spaces among the Palestinian Diaspora in Malmö. In: Jessica Retis \& Roza Tsagarousianou (eds.) The Handbook of Diasporas, Media, and Culture. Chichester: Wiley-Blackwell, pp. 531-546.

Chun, Wendy K. 2006. Control and Freedom: Power and Paranoia in the Age of Fiber Optics. Cambridge, MA: MIT.

Cohen, Robin 1997. Global Diasporas: An Introduction. Seattle: University of Washington Press.

Cohen, Robin 2020. 'Take me Home': The Coronavirus Virus and Panic Mobility. Compas, 20 March. Available at https://www.compas.ox.ac.uk/2020/take-me-home-thecoronavirus-virus-and-panic-mobility/, last accessed on 16 July 2020.

Davenel, Yves-Marie 2009. Are National Minorities of the Former USSR Becoming New Diasporas? The Case of the Tatars of Kazakhstan. In: Jane Fernandez (ed.) Diasporas. Critical and Interdisciplinary Perspectives. Oxford: Inter-Disciplinary Press, pp. 75-85. Available at https://www.academia.edu/1396863/, last accessed on 16 July 2020.

Estonian National Council 1956 = Estonian Culture in Exile: 10 Years of Estonian Cultural Activities in Sweden. Aims of Estonian Cultural Policy in Exile. Outlines of Estonian Cultural Policy. Stockholm: Estonian National Council.

Faist, Thomas 2012. Toward a Transnational Methodology: Methods to Address Methodological Nationalism, Essentialism, and Positionality. Revue européenne des migrations internationales, Vol. 28, No. 1, pp. 51-70. https://doi.org/10.4000/ remi.5761.

Fauser, Margit 2018. Mixed Methods and Multisited Migration Research: Innovations from a Transnational Perspective. Journal of Mixed Methods Research, Vol. 12, No. 4, pp. 394-412. http://dx.doi.org/10.1177/1558689817702752.

Fog Olwig, Karen 2007. Caribbean Journeys: An Ethnography of Migration and Home in Three Family Networks. Durham, NC: Duke University Press.

Fouron, Georges \& Glick Schiller, Nina 2001. All in the Family: Gender, Transnational Migration, and the Nation-State. Identities, Vol. 7, No. 4, pp. 539-582. https:// doi.org/10.1080/1070289X.2001.9962678.

Gamlen, Alan 2012. Mixing Methods in Research on Diaspora Policies. In: Carlos VargasSilva (ed.) Handbook of Methods in Migration. Cheltenham, UK \& Northampton, MA: Edward Elgar Publishing, pp. 319-341.

Gehring, Anoeshka 2019. Mobile Pensioners: Retirement Migrants' Perspectives of EU Citizenship and Free Movement. Innovation: The European Journal of Social Science Research, Vol. 32, No. 2, pp. 254-269. https://doi.org/10.1080/13511610 .2018.1525285. 
Glick Schiller, Nina \& Darieva, Tsypylma \& Gruner-Domic, Sandra 2011. Defining Cosmopolitan Sociability in a Transnational Age: An Introduction. Ethnic and Racial Studies, Vol. 34, No. 3, pp. 399-418. https://doi.org/10.1080/01419870.2 011.533781.

Glick Schiller, Nina \& Fouron, Georges E. 1999. Terrains of Blood and Nation: Haitian Transnational Social Fields. Ethnic and Racial Studies, Vol. 22, No. 2, pp. 340366. https://doi.org/10.1080/014198799329512.

Gold, Steven J. 2013. Using Photography in Studies of International Migration. In: Steven J. Gold \& Stephanie J. Nawyn (eds.) The Routledge International Handbook of Migration Studies. New York \& London: Routledge, pp. 530-542.

Gold, Steven J. \& Nawyn, Stephanie J. 2013. Introduction. In: Steven J. Gold \& Stephanie J. Nawyn (eds.) The Routledge International Handbook of Migration Studies. New York \& London: Routledge, pp. 1-8.

Gren, Nina 2015. Being Home through Learning Palestinian Sociality: SwedishPalestinian Houses in the West Bank. In: Florian Kläger \& Klaus Stierstorfer (eds.) Diasporic Constructions of Home and Belonging. Berlin: De Gruyter, pp. 229-247.

Hjorth, Larissa \& Lim, Sun Sun 2012. Mobile Intimacy in an Age of Affective Mobile Media. Feminist Media Studies, Vol. 12. No. 4, pp. 477-484. http://dx.doi.org/10 .1080/14680777.2012.741860.

Hoffmann, Eva 1999. The New Nomads. In: André Aciman (ed.) Letters of Transit: Reflections on Exile, Identity, Language, and Loss. New York: The New Press, pp. 39-63.

Hovgaard, Gestur 2015. Being Away; Being at Home; Being Both - The Case of Faroese Maritime Workers. In: Stine T. Faber \& Helene P. Nielsen (eds.) Remapping Gender, Place and Mobility: Global Confluences and Local Particularities in Nordic Peripheries. Surrey: Ashgate, pp. 175-189.

Ivask, Ivar 1951. Mõtteid eesti kirjanduskriitika ülesannetest. [Thoughts on the Tasks of Estonian Literary Criticism.] Tulimuld, No. 4, pp. 255-260.

Kissau, Kathrin \& Hunger, Uwe 2010. The Internet as a Means of Studying Transnationalism and Diaspora. In: Rainer Bauböck and Thomas Faist (eds.) Diaspora and Transnationalism: Concepts, Theories and Methods. Amsterdam: Amsterdam University Press, pp. 245- 265.

Korolainen, Kari 2019. Drawing Folklore, Things and Borders: Making of Comic Art and the Study of Folkloristic Archive Materials. SIEF2019 14th Congress "Track Changes: Reflecting on a Transforming World", Santiago de Compostela, Spain, 14-17 April 2019. Available at https://nomadit.co.uk/conference/sief2019/ paper/46776, last accessed on 16 July 2020.

Korolainen, Kari 2020a. Marjatta \& Ilman Kinna. [Marjatta and Ilman Kinna.] Joensuu: Kirjokansi.

Korolainen, Kari 2020b. Graphic Aspects of Mobility: Folkloristic-Ethnological Drawings as a Starting Point for Discussing Mobility and Borders. Folklore: Electronic Journal of Folklore, Vol. 79, pp. 115-136. https://doi.org/10.7592/FEJF2020.79. korolainen. 
Kozinets, Robert V. \& Dolbec, Pierre-Yann \& Earley, Amanda 2013. Netnographic Analysis: Understanding Culture through Social Media Data. In: Uwe Flick (ed.) The Sage Handbook of Qualitative Data Analysis. London \& Thousand Oaks, CA: SAGE, pp. 262-276.

Kuperjanov, Maris 2020. Koroonaviiruse SARS-CoV-2 algusfaasi vastukaja (sotsiaal) meedias. [Responses to the Initial Phase of SARS-CoV-2 in the (Social) Media.] Mäetagused, Vol. 76, pp. 5-28. https://doi.org/10.7592/MT2020.76.kuperjanov.

Latonero, Mark \& Kift, Paula 2018. On Digital Passages and Borders: Refugees and the New Infrastructure for Movement and Control. Social Media + Society, Vol. 4, No. 1, pp. 1-11. https://doi.org/10.1177/2056305118764432.

Levitt, Peggy 2009. Roots and Routes: Understanding the Lives of the Second Generation Transnationally. Journal of Ethnic and Migration Studies, Vol. 35, No. 7, pp. 1225-1242. https://doi.org/10.1080/13691830903006309.

Lintrop, Aado 1993. Udmurdi rahvausundi piirjooni. [Outlines of Udmurt Folk Religion.] Tartu: Tartu Ülikooli Kirjastus.

Lubbers, Miranda J. \& Verdery, Ashton M. \& Molina, José L. 2020. Social Networks and Transnational Social Fields: A Review of Quantitative and Mixed-Methods Approaches. International Migration Review, Vol. 54, No. 1, pp. 177-204. https:// doi.org/10.1177/0197918318812343.

Madianou, Mirca 2016. Ambient Co-Presence: Transnational Family Practices in Polymedia Environments. Global Networks, Vol. 16, No. 2, pp. 183-201. https:// doi.org/10.1111/glob.12105.

Madianou, Mirca 2019. Technocolonialism: Digital Innovation and Data Practices in the Humanitarian Response to Refugee Crises. Social Media + Society, Vol. 5, No. 3, pp. 1-13. https://doi.org/10.1177/2056305119863146.

Mikkilä, Elina 2020. Literary Biographies without a Fixed Linguistic Abode. Folklore: Electronic Journal of Folklore, Vol. 79, pp. 91-114. https://doi.org/10.7592/ FEJF2020.79.mikkila.

Nenov, Stoyan \& Escritt, Thomas 2020. Germany's Other Migration Wave: The Pensioner Exodus. Reuters, 16 January. Available at https://www.reuters.com/article/usgermany-pensioners/germanys-other-migration-wave-the-pensioner-exodusidUSKBN1ZF1B0, last accessed on 16 July 2020.

Oinas, Feliks J. 1974. The Position of the Setus in Estonian Folklore. Journal of Baltic Studies, Vol. 5, No. 1, pp. 18-25. https://doi.org/10.1080/01629777400000431.

Ojamaa, Triinu 2011. 60 aastat eesti koorilaulu multikultuurses Torontos. [60 Years of Estonian Choral Singing in Multicultural Toronto.] Tartu: EKM Teaduskirjastus.

Ojamaa, Triinu \& Kurvet-Käosaar, Leena 2020. Conceptual Alignments and Debates in the Study of Mobility and Migration: An Introduction. Folklore: Electronic Journal of Folklore, Vol. 78, pp. 7-24. https://doi.org/10.7592/FEJF2020.78.introduction.

Olesk, Sirje 2007. Ivar Ivaski päevikud: Saateks ja selgituseks. [Ivar Ivask's Diaries: Preface.] In: S. Olesk (comp.) I. Ivask. Olla need, kes me oleme. Katkeid päevikutest aastatel 1964-1992. Tartu: EKM Teaduskirjastus, pp. 5-11.

Olszewska, Zuzanna 2019. Writing in Diaspora. In: Robin Cohen \& Carolin Fischer (eds.) Routledge Handbook of Diaspora Studies. Abington \& New York: Routledge, pp. 86-94. 
Oras, Ants 1967. Estonian Literature in Exile: An Essay. With a Bio-bibliographical Appendix by Bernard Kangro. Lund: Eesti Kirjanike Kooperatiiv.

Pileva, Desislava 2020. From Mobility to "Exile". Shifting Co-presence: Narratives of Bulgarian-Syrian Families in Bulgaria. Folklore: Electronic Journal of Folklore, Vol. 78, pp. 41-60. https://doi.org/10.7592/FEJF2020.78.pileva.

Pollock, Sheldon \& Bhabha, Homi K. \& Breckenridge, Carol A. \& Chakrabarty, Dipesh 2000. Cosmopolitanisms: Introduction. Public Culture, Vol. 12, No. 3, pp. 577-589. https://doi.org/10.1215/08992363-12-3-577.

Ponzanesi, Sandra (ed.) 2019. Special Issue: Migration and Mobility in a Digital Age: (Re)Mapping Connectivity and Belonging. Television \& New Media, Vol. 20, No. 6.

Ponzanesi, Sandra 2020a. Digital Cosmopolitanism: Notes from the Underground. Global Perspectives, Vol. 1, No. 1, pp. 1-13. https://doi.org/10.1525/gp.2020.12548.

Ponzanesi, Sandra 2020b. Digital Diasporas: Postcoloniality, Media and Affect. Interventions: International Journal of Postcolonial Studies. Online. https://doi.org/1 0.1080/1369801X.2020.1718537.

Portes, Alejandro 2003. Conclusion: Theoretical Convergencies and Empirical Evidence in the Study of Immigrant Transnationalism. International Migration Review, Vol. 37, No. 3, pp. 874-892. https://doi.org/10.1111/j.1747-7379.2003.tb00161.x.

Repetti, Marion \& Phillipson, Christopher \& Calasanti, Toni 2018. Retirement Migration in Europe: A Choice for a Better Life? Sociological Research Online, Vol. 23, No. 4, pp. 780-794. https://doi.org/10.1177/1360780418782243.

Risam, Roopika 2019. Beyond the Migrant "Problem": Visualizing Global Migration. Television \& New Media, Vol. 20, No. 6, pp. 566-580. https://doi. org/10.1177/1527476419857679.

Safran, William 1991. Diasporas in Modern Society: Myth of Homeland and Return. Diaspora: A Journal of Transnational Studies, Vol. 1, No. 1, pp. 83-99. https:// doi.org/10.1353/dsp.1991.0004.

Sakova, Aija \& Laak, Marin 2020. Situating Oneself within the Estonian Language and World Literature: Ivar Ivask's Relational Ways of Self-Understanding. Folklore: Electronic Journal of Folklore, Vol. 79, pp. 71-90. https://doi.org/10.7592/ FEJF2020.79.sakova_laak.

Saresma, Tuija 2019. Mohsen Emadi - A Poet of Exile. Trames: Journal of the Humanities and Social Sciences, Vol. 23, No. 2, pp. 203-221. https://doi.org/10.3176/ tr.2019.2.06.

Smets, Kevin 2019. Doing Diasporic Media Research: Methodological Challenges and Innovations. In: Jessica Retis \& Roza Tsagarousianou (eds.) The Handbook of Diasporas, Media, and Culture. Chichester: Wiley-Blackwell, pp. 97-112.

Taagepera, Rein 1999. The Finno-Ugric Republics and the Russian State. London: Hurst \& Company.

Tashakkori, Abbas \& Cresswell, John W. 2007. The New Era of Mixed Methods. Journal of Mixed Methods Research, Vol. 1, No. 1, pp. 3-7. https://doi. org/10.1177\%2F1558689806293042.

Toulouze, Eva \& Anisimov, Nikolai 2020. An Ethno-cultural Portrait of a Diaspora in Central Russia: The Formation and Culture of the Eastern Udmurt. Folklore: Electronic Journal of Folklore, Vol. 79, pp. 31-58. https://doi.org/10.7592/ FEJF2020.79.toulouze_anisimov. 
Tsuda, Takeyuki (Gaku) 2019. Diasporicity: Relative Embeddedness in Transnational and Co-ethnic Networks. In: Robin Cohen \& Carolin Fisher (eds.) Routledge Handbook of Diaspora Studies. Abington \& New York: Routledge, pp. 189-196.

Uus Eesti 1938 = Ivan Bunin Eestis. [Ivan Bunin in Estonia.] Uus Eesti, 6 May, No. 124, p. 4.

Vargas-Silva, Carlos (ed.) 2012. Handbook of Research Methods in Migration. Cheltenham, UK \& Northampton, MA: Edward Elgar.

Vertovec, Steven 2018. Religion and Diaspora. In: Klaus Stierstorfer \& Janet Wilson (eds.) The Routledge Diaspora Studies Reader. London \& New York: Routledge Taylor \& Francis Group, pp. 25-35.

Volkmer, Ingrid (ed.) 2012. The Handbook of Global Media Research. Chichester: WileyBlackwell.

White, Michael J. 2016. International Handbook of Migration and Population Distribution. Heidelberg \& New York \& London: Springer.

Witteborn, Saskia 2014. Forced Migrants, Emotive Practice and Digital Heterotopia. Crossings: Journal of Migration and Culture, Vol. 5, No. 1, pp. 73-85. http:// dx.doi.org/10.1386/cjmc.5.1.73_1.

Witteborn, Saskia 2019. Digital Diaspora: Social Alliances beyond the Ethnonational Bond. In: Jessica Retis \& Roza Tsagarousianou (eds.) The Handbook of Diasporas, Media, and Culture. Chichester: Wiley-Blackwell, pp. 179-192.

Woodrow-Lafield, Karen A. 2013. Census Analysis. In: Steven J. Gold \& Stephanie J. Nawyn (eds.) The Routledge International Handbook of Migration Studies. New York \& London: Routledge, pp. 471-483.

Zuckerman, Ethan 2013. Digital Cosmopolitans: Why We Think the Internet Connects Us, Why It Doesn't, and How to Rewire It. New York \& London: W. W. Norton.

Leena Kurvet-Käosaar is associate professor of cultural theory $(\mathrm{PhD})$ at the University of Tartu, Estonia, senior research fellow at the Estonian Literary Museum and, together with Triinu Ojamaa, the leader of the research group on migration and diaspora studies of the Centre of Excellence in Estonian Studies. Her main research areas include life-writing studies, migration studies, personal narratives of Soviet deportations and the Gulag, and trauma studies.

leena.kurvet-kaosaar@ut.ee

Triinu Ojamaa is senior research fellow $(\mathrm{PhD})$ at the Estonian Literary Museum, Estonia, and, together with Leena Kurvet-Käosaar, the leader of the research group on migration and diaspora studies of the Centre of Excellence in Estonian Studies. Her main research areas are diasporic identity, adaptation strategy, and inter-ethnic relations in diaspora communities.

triinu.ojamaa@kirmus.ee 